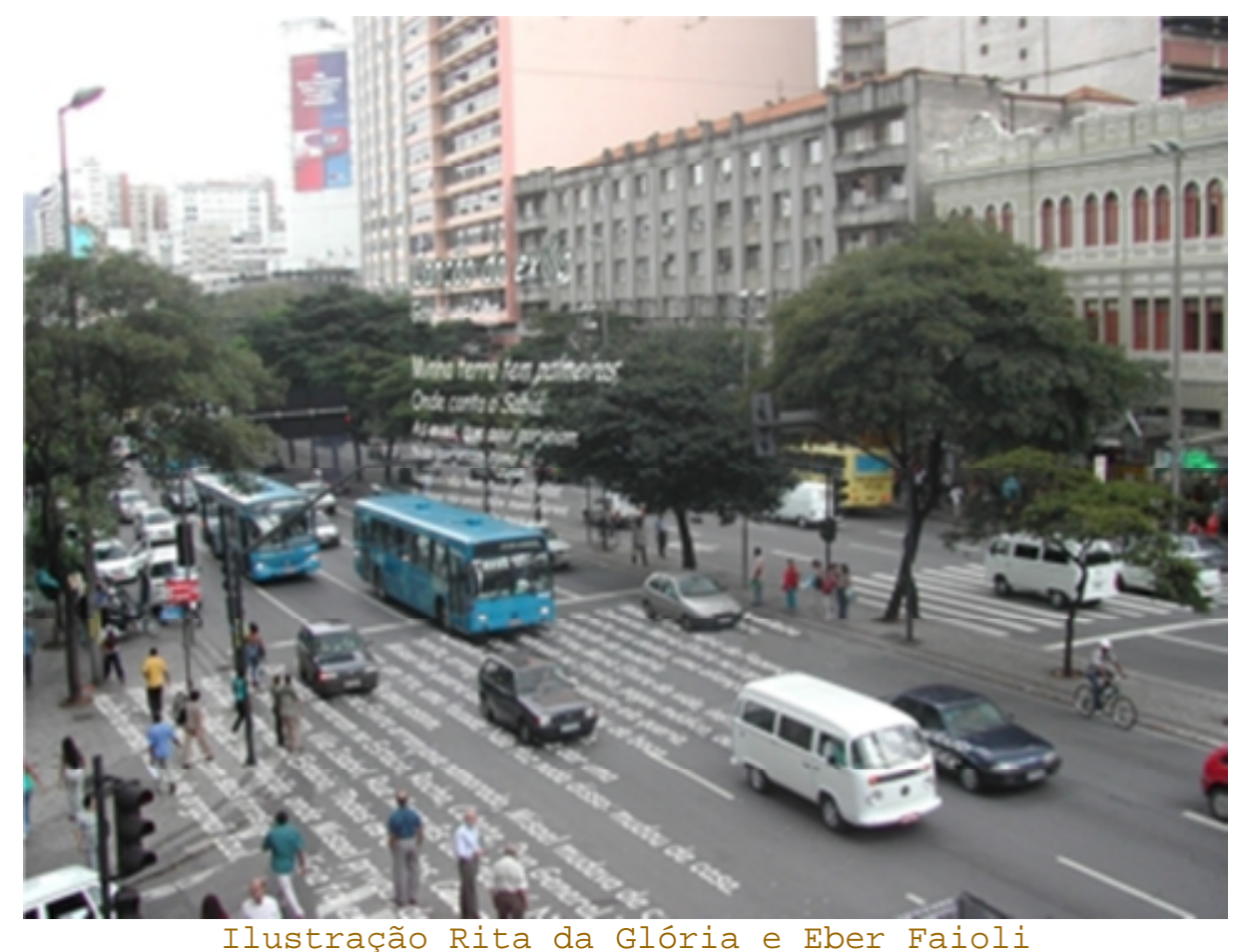

\title{
Claro que brasileiro gosta de ler!
}

\author{
Humberto Rolo Paulino \\ por Kênia Aulízia Herédia
}

Humberto Rolo Paulino é Gerente de Coordenação de Comunicação e Educação da BHTRANS/ Belo Horizonte.

Kênia Aulizia Herédia é membro da coordenação coletiva do Programa A tela e o texto, Mestre em Teoria da Literatura (FALE/UFMG) e professora da rede municipal de Belo Horizonte.

Kênia Aulízia Herédia - Há algum tempo o senhor declarou que, juntamente com a televisão e o rádio, o ônibus é uma grande mídia. Recentemente, a população de Belo Horizonte tem visto a implementação de projetos de inclusão cultural na frota da cidade. 0 senhor poderia falar um pouco sobre eles?

Humberto Rolo Paulino - Sinceramente não me lembro de ter feito essa afirmação (o ônibus é uma grande mídia), até me considero um crítico da verdadeira invasão de todos os espaços possíveis e imagináveis 
para transformá-los em mídia. Haja sossego para os nossos olhos e ouvidos!

Por algumas vezes já recebemos, na BHTRANS, propostas de criação de uma rádio nos ônibus urbanos, para veiculação de música, notícias e, é claro, mensagens comerciais, institucionais, politizantes etc. As possibilidades seriam diversas mas, no que depender de mim, serei sempre contra. Acho absurdo impor a uma pessoa o que ouvir ou, o pior, impossibilitar o direito de não ouvir nada (já bastam os ruídos do trânsito, do motor etc.).

Temos o Jornal do Ônibus, que existe desde 1994, e as pesquisas indicam ser lido por $60 \%$ da população de Belo Horizonte, com quase unânime avaliação positiva e, mais recentemente, o projeto Arte no Ônibus que, a meu ver, é um exemplo de iniciativa criativa e cidadã.

Depois do Arte no Ônibus, os usuários de transporte coletivo de BH deparam-se com o projeto Leitura para Todos. Como surgiu a idéia de transformar os ônibus em "bibliotecas"?

A idéia veio de vocês, do grupo A tela e o texto, é claro! Fui apresentado à Professora Maria Antonieta pela vereadora Neila Batista - se não me engano, em abril do ano passado - e me foi feita a proposta de disponibilizar textos para leitura nos ônibus de Belo Horizonte. Gostei "de cara" da idéia, pois ela alia a possibilidade de uma distração para os passageiros que, em muitos casos, passam horas de seus dias nos ônibus, à missão de oferecer cultura, de boa qualidade, a muitas pessoas $(70 \%$ da população de BH utilizam ônibus) .

Em várias reuniões que tivemos, envolvendo outras pessoas da BHTRANS e da FALE, fomos formatando o projeto-piloto e até hoje estamos ocupados em melhorá-lo.

Como tem sido a recepção dessa iniciativa por parte da população? Tendo em vista a reação das pessoas, como o senhor avalia a questão da leitura? Brasileiro realmente não gosta de ler?

Acho que o projeto, sem exagero algum, é das melhores idéias já surgidas em termos de responsabilidade social, conceito (afortunadamente) muito em voga. Tenho certeza de que, quando o viabilizarmos para a totalidade da frota de ônibus de Belo Horizonte, ele se transformará em exemplo para todo o país.

Lidamos diariamente na BHTRANS com questões que afetam toda a população e é comum o assédio da imprensa, das TVs, das rádios mas, no caso desse projeto, impressiona o interesse constante que ele desperta.

Quanto aos usuários, que são realmente o que importa nessa história, é impossível ser maior a aprovação. Digo isso em função da 
observação direta feita nos ônibus por nós e por alunos e professores da FALE, por e-mail, cartas e telefonemas de elogio, mas principalmente por termos tido a preocupação de fazer uma pesquisa com cerca de 200 passageiros, na qual constatamos que 82\% leram textos e que 96\% destes gostaram do projeto.

Bom ... se esses dados e o grande sucesso do projeto não servem para desmistificar essa idéia de que brasileiro não gosta de ler ... Claro que gosta! E se não gostasse teríamos um motivo maior ainda para insistirmos em projetos como esse. 